\section{Growth and Flowering Responses of Seed-propagated Strawberry Seedlings to Different Photoperiods in Controlled Environment Chambers}

\author{
Johshin Tsuruyama ${ }^{1,2}$ and Toshio Shibuya ${ }^{2,3}$
}

AdDITIONAL INDEX WORDs. artificial lighting, Fragaria $\times$ ananassa, growth analysis, light-emitting diode, long-day treatment, strawberry plug transplant

SUMMARY. The present study investigated growth properties and flowering response of seed-propagated strawberry (Fragaria $\times$ ananassa) seedlings under artificial lighting with different photoperiods to support the development of a highperformance system for the indoor production of strawberry plug transplants. Seedlings of 'Elan' and 'Yotsuboshi' were grown for 38 days under sunlight in a greenhouse or under light-emitting diode (LED) illumination with photoperiods of $8 / 16,12 / 12,16 / 8$, or $24 / 0$ hours (light/dark) in growth chambers. The photosynthetic photon flux $(P P F)$ in these photoperiods was maintained at 350, 230,175 , or $115 \mu \mathrm{mol} \cdot \mathrm{m}^{-2} \cdot \mathrm{s}^{-1}$, respectively, to provide the same daily light integral (DLI) of $10 \mathrm{~mol} \cdot \mathrm{m}^{-2} \cdot \mathrm{d}^{-1}$. The average of DLI of sunlight was $9.9 \mathrm{~mol} \cdot \mathrm{m}^{-2} \cdot \mathrm{d}^{-1}$. Seedling growth was greater with the 16- and 24-hour photoperiods than with sunlight even though all three treatments provided about the same DLI. Flower buds of the seedlings grown under longer photoperiods started significantly earlier after transplanting in 'Elan' but not in 'Yotsuboshi'. Thus, strawberry transplant production under artificial lighting with an optimized photoperiod can provide highquality transplants, although the effectiveness is cultivar-specific.

$\mathrm{P}$ lug transplants of strawberry have been replacing traditional bare-root transplants despite their higher costs because the newer approach can reduce the incidence of soilborne disease and improve transplant quality under a controlled environment (Bish et al., 2001, 2002; Durner et al., 2002; López-Galarza et al., 2010). The strawberry plugs are generally produced vegetatively; runner tips harvested from mother plants are planted in growing medium and grown in greenhouses. In addition, seed-propagated strawberry cultivars have been attracting attention for

This research was supported by the Japan Society for the Promotion of Science Grants-in-Aid for Scientific Research (B) (KAKENHI 15H04575, 18H02307) and by the NARO Bio-oriented Technology Research Advancement Institution (the special scheme project on regional developing strategy)

We thank Akihiro Maejima (Hananoumi Co. Ltd.) for his support in the environmental control in the greenhouse and Dr. Tomoaki Jishi (Central Research Institute of Electric Power Industry) for his technical support in controlling light conditions.

${ }^{1}$ Yamaguchi Prefectural Agriculture \& Forestry General Technology Center, 1-1-1 Ouchi-Hikami, Yamaguchi 753-0231, Japan

${ }^{2}$ Graduate School of Life and Environmental Sciences, Osaka Prefecture University, 1-1 Gakuen-cho, Naka-ku, Sakai 599-8531, Japan

${ }^{3}$ Corresponding author. E-mail: shibuya@envi.osakafu-u. ac.jp.

https://doi.org/10.21273/HORTTECH04061-18 plug production (Bentvelsen and Bouw, 2006) because many $F_{1}$ hybrid strawberry cultivars, which are propagated by seeds, have been developed since the 1990s. Most of them were produced for the ornamental market, but recently, cultivars for fresh fruit market have developed in northwestern Europe for extending greenhouse production through the winter off-season (Bentvelsen and Souillat, 2017). In Japan, a seed-propagated cultivar, Yotsuboshi, has been developed that has fruit quality and productivity similar to those of other popular commercial cultivars and that is expected to permit year-round production (Mochizuki et al., 2016; Mori et al., 2015). To support the growing demand, a high-performance production system based on seedpropagated strawberry plugs will be required.

Here, the authors focus on indoor transplant production systems using artificial lighting (Kozai, 2007; Kozai et al., 2006), which are used for commercial vegetable and ornamental crops. In these systems, environmental factors, such as temperature and humidity, can be easily controlled regardless of weather conditions. This approach would be particularly effective for strawberry plug production from late spring to summer because high temperatures during plug production can delay flowering and reduce subsequent fruit yield (Bish et al., 2002). In addition to thermal conditions, light conditions, such as the light intensity and photoperiod, can be controlled in an indoor system. Thus, plug production using artificial lighting with an optimal photoperiod would produce high-quality strawberry plugs because flowering could be controlled by changing the photoperiod during transplant production (Durner, 2016; Sønsteby and Heide, 2007a, 2007b). However, although a longer photoperiod can stimulate flower bud initiation by long-day cultivars, it may be necessary to decrease light intensity to avoid an expensive increase in energy consumption for artificial lighting. Thus, photoperiod may influence plant growth through the required change in light intensity. In the present study, the growth properties and flowering response of two seed-propagated long-day strawberry cultivars were investigated under sunlight or LED illumination with different photoperiods.

\section{Materials and methods}

Plant materials and growing CONDITIONS. Seeds of the strawberry cultivars Elan and Yotsuboshi were

\begin{tabular}{llll}
\hline $\begin{array}{l}\text { Units } \\
\text { To convert U.S. to SI, } \\
\text { multiply by }\end{array}$ & U.S. unit & SI unit & $\begin{array}{l}\text { To convert SI to U.S., } \\
\text { multiply by }\end{array}$ \\
\hline 100 & $\mathrm{bar}$ & $\mathrm{kPa}$ & 0.01 \\
29.5735 & $\mathrm{fl} \mathrm{oz}$ & $\mathrm{mL}$ & 0.0338 \\
0.3048 & $\mathrm{ft}$ & $\mathrm{m}$ & 3.2808 \\
0.0929 & $\mathrm{ft}^{2}$ & $\mathrm{~m}^{2}$ & 10.7639 \\
0.0033 & $\mathrm{ft}^{2} / \mathrm{oz}$ & $\mathrm{m}^{2} \cdot \mathrm{g}^{-1}$ & 305.1517 \\
25.4 & inch $(\mathrm{es})$ & $\mathrm{mm}$ & 0.0394 \\
6.4516 & inch & $\mathrm{cm}^{2}$ & 0.1550 \\
28.3495 & $\mathrm{oz}$ & $\mathrm{g}$ & 0.0353 \\
28,350 & $\mathrm{oz}$ & $\mathrm{mg}$ & $3.5274 \times 10^{-5}$ \\
305.1517 & $\mathrm{oz} / \mathrm{ft}^{2}$ & $\mathrm{~g} \cdot \mathrm{m}^{-2}$ & 0.0033 \\
$\left({ }^{\circ} \mathrm{F}-32\right) \div 1.8$ & ${ }^{\circ} \mathrm{F}$ & ${ }^{\circ} \mathrm{C}$ & $\left({ }^{\circ} \mathrm{C} \times 1.8\right)+32$
\end{tabular}


sown in a soil mix containing a mixture of peatmoss and vermiculite (Sumika Agrotech Co., Osaka, Japan) in plastic cell-trays $[545 \mathrm{~mm}$ length (L) $\times 280 \mathrm{~mm}$ width $(\mathrm{W}) \times 20 \mathrm{~mm}$ height $(\mathrm{H})]$ that contained 406 square cells ( $15.7 \mathrm{~mm}$ square). The plant density was 2661 plants $/ \mathrm{m}^{2}$. The seeds were then germinated in a germination chamber at an air temperature of $25^{\circ} \mathrm{C}$, a relative humidity of $\approx 100 \%$, and a $P P F$ of $20 \mu \mathrm{mol} \cdot \mathrm{m}^{-2} \cdot \mathrm{s}^{-1}$ continuously provided by white LED lamps (manufacturer unknown). When the second true leaf had initiated $(23 \mathrm{~d}$ after sowing), the seedlings were transplanted into the same soil mix in plastic cell-trays [ $280 \times 273 \times 44 \mathrm{~mm}(\mathrm{~L} \times \mathrm{W}$ $\times \mathrm{H})$; half the size of a standard 72-cell tray] with 36 square cells $(38-\mathrm{mm}$ diameter). The plant density was 471 plants $/ \mathrm{m}^{2}$. A small-particle fertilizer (14N-4.8P-10.8K; JCAM Agri, Tokyo, Japan) was mixed thoroughly into the soil before transplanting. The amount of nitrogen per seedling was $280 \mathrm{mg}$.

Five trays with 36 seedlings were prepared for each cultivar and then were placed under LED illumination with one of four different photoperiods or under sunlight (as the control). A growth chamber (LH-30-8CT; Nippon Medical \& Chemical Instruments Co., Osaka, Japan) with eight individual sub-chambers [each $330 \times$ $330 \times 300 \mathrm{~mm}(\mathrm{~L} \times \mathrm{W} \times \mathrm{H})]$ was used to create the photoperiod treatments. The seedlings were grown for $38 \mathrm{~d}$ at a photoperiod of $8 / 16,12 / 12$, $16 / 8$, or $24 / 0 \mathrm{~h}$ (light/dark); in the sunlight control, the photoperiod ranged from 12.8 to $14.0 \mathrm{~h}$ during the study period. The $P P F$ at each photoperiod was maintained at 350 , 230,175 , or $115 \mu \mathrm{mol} \cdot \mathrm{m}^{-2} \cdot \mathrm{s}^{-1}$, respectively, to provide the same DLI $\left(10 \mathrm{~mol} \cdot \mathrm{m}^{-2} \cdot \mathrm{d}^{-1}\right)$. Illumination was supplied by LED panels [each $310 \times$ $280 \mathrm{~mm}(\mathrm{~L} \times \mathrm{W})$ ] containing blue LEDs with a peak wavelength of $470 \mathrm{~nm}$ (OSUB5161P; Optosupply, Hong Kong, China) and red LEDs with a peak wavelength of $625 \mathrm{~nm}$ (OS5RKA5B61P, Optosupply). The blue:red $P P F$ ratio was 1:2 (Fig. 1). Air temperature was maintained at $25^{\circ} \mathrm{C}$. Relative humidity was not rigorously controlled but was maintained between $55 \%$ and $60 \%$ [equivalent to a vapor pressure deficit (VPD) of 1.43 and $1.27 \mathrm{kPa}$, respectively] during the light period and between $65 \%$ and $70 \%$ (a VPD of 1.11 and $0.95 \mathrm{kPa}$,

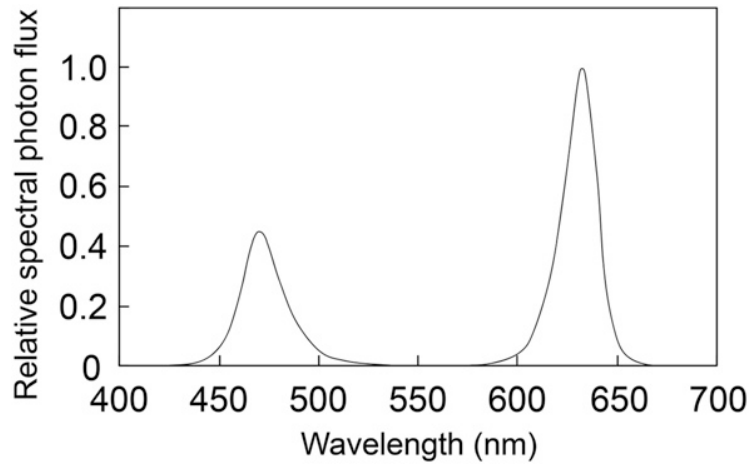

Fig. 1. Light spectrum of the light-emitting diodes that were used for the photoperiod treatment. Photon flux per unit wavelength are expressed relative to the maximum.

respectively) during the dark period. The carbon dioxide concentration was not controlled and was at the same level as the ambient air. Water was supplied once a day to field capacity. The seedlings in the sunlight treatment were grown in a greenhouse at Hananoumi Co. [Sanyou-onoda, Japan (lat. $34.0^{\circ} \mathrm{N}$, long. $131.1^{\circ} \mathrm{E}$ )] for $38 \mathrm{~d}$ (3 July to 10 Aug. 2017 ) to provide a control for comparison with the conventional production system. In the greenhouse, the air temperature was controlled by shading during the day and by cooling with an air conditioner during the night.

Evaluation OF GROWTH PROPERTIES. Ten seedlings in each treatment group were sampled at the start of treatment and after $38 \mathrm{~d}$ and then their dry weight, leaf area, leaf number, and maximum petiole $L$ were recorded. The relative growth rate (RGR), net assimilation rate (NAR), and leaf area ratio (LAR) were calculated using the following equations (Hunt et al., 2002; Radford, 1967):

$$
\begin{aligned}
\mathrm{RGR} & =\frac{\ln W_{2}-\ln W_{1}}{t_{2}-t_{1}}=\mathrm{NAR} \times \mathrm{LAR}, \\
\mathrm{NAR} & =\frac{W_{2}-W_{1}}{A_{2}-A_{1}} \times \frac{\ln A_{2}-\ln A_{1}}{t_{2}-t_{1}}, \\
\mathrm{LAR} & =\frac{A_{2}-A_{1}}{\ln A_{2}-\ln A_{1}} \times \frac{\ln W_{2}-\ln W_{1}}{W_{2}-W_{1}},
\end{aligned}
$$

where $W_{1}$ and $W_{2}$ are the total dry weight (grams/plant) at times $t_{1}$ and $t_{2}$ $(0$ and $38 \mathrm{~d}$ after the start of treatment, respectively), $A_{1}$ and $A_{2}$ are the corresponding total leaf areas (square meters/ plant), and $L_{1}$ and $L_{2}$ are the corresponding leaf dry weights (grams/plant).

EVALUATION OF FLOWER BUD INITIATION AFTER TRANSPLANTING.
Twenty-five seedlings from most treatments and 38 seedlings of 'Elan' grown under sunlight were transplanted into the growing medium (Sunpoly Co., Houfu, Japan) containing a mixture of $1 / 3$ coconut peat, $1 / 3$ bark compost, and $1 / 3$ (by vol) rockwool in planters $[18 \mathrm{~m} \times 0.26 \mathrm{~m} \times 135 \mathrm{~mm}(\mathrm{~L} \times \mathrm{W} \times$ $\mathrm{H})$ ] at intervals of $200 \mathrm{~mm}$, and then were grown for $110 \mathrm{~d}$ (10 Aug. to 28 Nov. 2017) in another greenhouse at the Yamaguchi Prefectural Agriculture \& Forestry General Technology Center [Yamaguchi, Japan (lat. $34.2^{\circ} \mathrm{N}$, long. $\left.131.5^{\circ} \mathrm{E}\right)$ ]. The small-particle fertilizer $(14 \mathrm{~N}-4.8 \mathrm{P}-10.8 \mathrm{~K})$ was mixed into the soil before transplanting. The amount of nitrogen per plant was $280 \mathrm{mg}$. Each plant was irrigated with $120 \mathrm{~mL}$ of tap water once a day, using a drip irrigation system. The strawberry plants were examined daily after transplantation to detect flower buds.

Statistical analysis. The experiment was performed once, without replication because of limited growth chamber space. Ten seedlings were prepared as biological replications for evaluating the growth parameters, and 25 plants were used for evaluating flower bud initiation, except for 'Elan' under sunlight $(n=$ 38); however, three to five plants died within 1 week after transplantation in the 8-, 12-, 16-, and 24-h treatments with 'Yotsuboshi', leaving only $22,20,22$, and 20 samples, respectively. The effects of the treatment on each parameter were determined by analysis of variance. Significant differences between treatments were identified by the Tukey-Kramer test $(P$ $<0.05$ ) for seedlings from all cultivars and in all light treatments, and between light treatments within each cultivar. All analyses were performed in $\mathrm{R}$ software (The R Foundation, Vienna, Austria). 
Table 1. Light and thermal conditions in the growth chambers with light-emitting diodes (LEDs) and in the greenhouse (with sunlight) during the treatment period. The changes in these conditions in the greenhouse are shown in Fig. 2.

\begin{tabular}{|c|c|c|c|c|c|c|}
\hline Light source & Photoperiod (h) & $P P F\left(\mu \mathrm{mol} \cdot \mathrm{m}^{-2} \cdot \mathrm{s}^{-1}\right)$ & $\begin{array}{c}\text { DLI } \\
\left(\mathrm{mol} \cdot \mathrm{m}^{-2} \cdot \mathrm{d}^{-1}\right)^{\mathrm{z}}\end{array}$ & $\begin{array}{c}\text { Day } \\
\text { temp }\left({ }^{\circ} \mathrm{C}\right)^{y}\end{array}$ & $\begin{array}{c}\text { Night } \\
\text { temp }\left({ }^{\circ} \mathrm{C}\right)\end{array}$ & $\begin{array}{c}\text { Avg. } \\
\text { temp }\left({ }^{\circ} \mathrm{C}\right)\end{array}$ \\
\hline \multirow[t]{4}{*}{ LEDs } & 8 & 350 & 10 & 25.0 & 25.0 & 25.0 \\
\hline & 12 & 230 & 10 & 25.0 & 25.0 & 25.0 \\
\hline & 16 & 175 & 10 & 25.0 & 25.0 & 25.0 \\
\hline & 24 & 115 & 10 & 25.0 & 25.0 & 25.0 \\
\hline Sunlight & 13.6 & $211^{\mathrm{x}}$ & 9.9 & 30.1 & 22.7 & 26.8 \\
\hline
\end{tabular}

${ }^{\mathrm{z}}$ Daily light integral.

$\mathrm{y}\left(1.8 \times{ }^{\circ} \mathrm{C}\right)+32={ }^{\circ} \mathrm{F}$

${ }^{x}$ Average of daytime $P P F$.

$P P F=$ photosynthetic photon flux.

\section{Results and discussion}

LIGHT AND THERMAL CONDITIONS. The average DLI in the greenhouse was equivalent to that in the chambers (Table 1), whereas daytime PPF fluctuated from 0 to $1800 \mu \mathrm{mol} \cdot \mathrm{m}^{-2} \cdot \mathrm{s}^{-1}$ in the greenhouse (Fig. 2). The mean daylength of $13.6 \mathrm{~h}$ in the greenhouse was intermediate between those of the 12- and 16-h treatments. The air temperature in the greenhouse fluctuated from 20 to $38^{\circ} \mathrm{C}$ (Fig. 2). The average temperature in the greenhouse was only $1.8{ }^{\circ} \mathrm{C}$ higher than that in the chambers. The VPD fluctuated from 0.1 to $3.2 \mathrm{kPa}$ (Fig. 2). After transplantation, the air temperature in the greenhouse fluctuated from 24 to $40^{\circ} \mathrm{C}$ during the first 3 weeks and then gradually decreased (Fig. 3).

In the present experimental design, light intensity varied with photoperiod, so it was not possible to separate the effects of photoperiod from those of light intensity. In future research, authors plan to test the effects of different light intensities at the optimal photoperiod identified in the present study.

Growth PARAMETERS. The dry weight and leaf area of both cultivars increased with increasing photoperiod under LED illumination, and the differences were significant at the longest photoperiods, except for the leaf area of 'Elan', but the number of leaves did not differ significantly among the treatments, except for a significantly lower number under sunlight in 'Yotsuboshi' (Table 2). The RGR of seedlings grown under LEDs with a 12-, 16-, and 24-h photoperiod were, respectively, $103 \%, 117 \%$, and $126 \%$ of the RGR under an 8 -h photoperiod in 'Elan' vs. 108\%, 116\%, and $117 \%$, respectively, in 'Yotsuboshi' (Table 3). The increased RGR at longer photoperiods can be explained mainly by the significantly greater

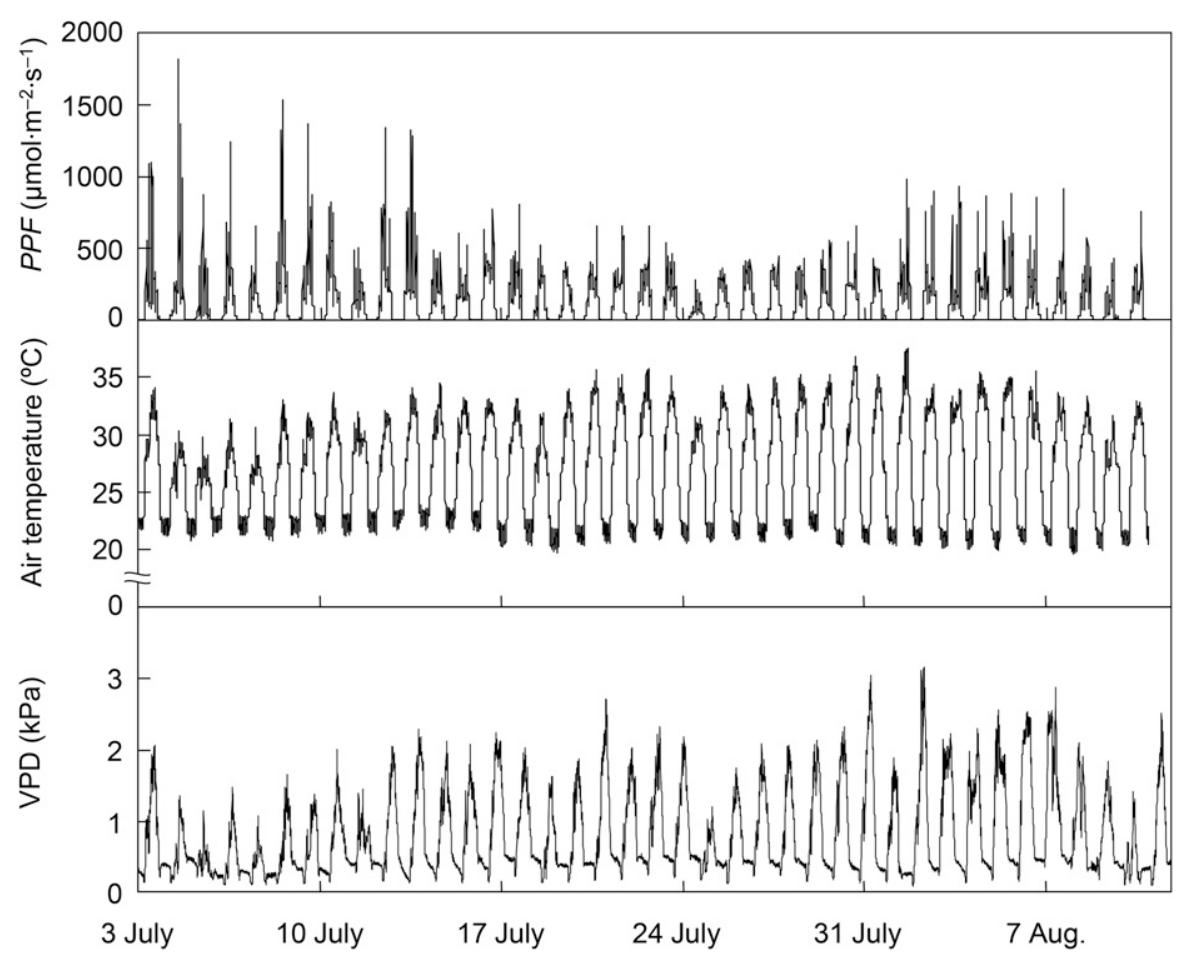

Fig. 2. Changes in the photosynthetic photon flux $(P P F)$, air temperature, and vapor-pressure deficit (VPD) in the greenhouse (Hananoumi Co., Ltd.), in which strawberry seedlings were grown as the control during the treatment period. Air temperature was controlled by shading during the day and by cooling with an air conditioner during the night. The average light and thermal conditions in the greenhouse are shown in Table $1 ;\left(1.8 \times{ }^{\circ} \mathrm{C}\right)+32={ }^{\circ} \mathrm{F}, 1 \mathrm{kPa}=0.01 \mathrm{bar}$.

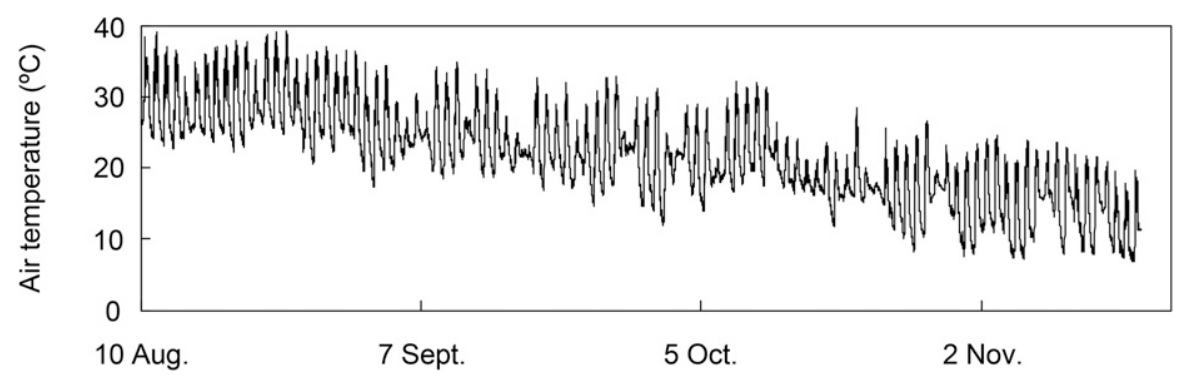

Fig. 3. Changes in the air temperature in the greenhouse (Yamaguchi Prefectural Agriculture \& Forestry General Technology Center) after transplanting of the strawberry seedlings; $\left(1.8 \times{ }^{\circ} \mathrm{C}\right)+32={ }^{\circ} \mathrm{F}$. 
Table 2. Dry weight, leaf area, number of leaves, and petiole length of seedlings of the two strawberry cultivars grown under light-emitting diode (LED) illumination with different photoperiods (in the growth chambers) or under sunlight (in the greenhouse). Values were measured $38 \mathrm{~d}$ after the start of the photoperiod treatment. The light and thermal conditions in the growth chambers and the greenhouse are shown in Table 1 and Fig. 2. Data are the average of 10 replication plants $(n=10)$.

\begin{tabular}{|c|c|c|c|c|c|c|}
\hline Cultivar & Light source & Photoperiod (h) & Dry wt $(\mathrm{mg})^{\mathrm{z}}$ & Leaf area $\left(\mathrm{cm}^{2}\right)^{\mathrm{z}}$ & Leaves (no.) & Petiole length $(\mathrm{mm})^{z}$ \\
\hline \multirow[t]{4}{*}{ Elan } & LEDs & 8 & $144 \mathrm{~d}, \mathrm{C}^{\mathrm{y}}$ & $28.3 \mathrm{df}, \mathrm{AB}$ & $6.8 \mathrm{ad}, \mathrm{A}$ & $17 \mathrm{~d}, \mathrm{~B}$ \\
\hline & & 12 & $166 \mathrm{~d}, \mathrm{C}$ & $26.2 \mathrm{ef}, \mathrm{AB}$ & $6.9 \mathrm{ad}, \mathrm{A}$ & $15 \mathrm{~d}, \mathrm{~B}$ \\
\hline & & 16 & 247 b,B & $27.6 \mathrm{df}, \mathrm{AB}$ & $6.5 \mathrm{bcd}, \mathrm{A}$ & $19 \mathrm{~cd}, \mathrm{~B}$ \\
\hline & Sunlight & 13.6 & 144 d,C & $22.8 \mathrm{f}, \mathrm{B}$ & $6.3 \mathrm{~d}, \mathrm{~A}$ & $31 \mathrm{~b}, \mathrm{~A}$ \\
\hline \multirow[t]{4}{*}{ Yotsuboshi } & LEDs & 8 & $175 \mathrm{~cd}, \mathrm{C}$ & 35.7 cde, $C$ & $7.2 \mathrm{ab}, \mathrm{A}$ & 25 bd,B \\
\hline & & 12 & 232 bc, B & $34.5 \mathrm{ac}, \mathrm{AC}$ & $7.4 \mathrm{a}, \mathrm{A}$ & $29 \mathrm{bc}, \mathrm{B}$ \\
\hline & & 24 & $325 \mathrm{a}, \mathrm{A}$ & $46.9 \mathrm{ab}, \mathrm{AB}$ & $7.0 \mathrm{ad}, \mathrm{AB}$ & $74 \mathrm{a}, \mathrm{A}$ \\
\hline & Sunlight & 13.6 & $205 \mathrm{bd}, \mathrm{BC}$ & 37.7 bcd,BC & $6.4 \mathrm{~cd}, \mathrm{~B}$ & $71 \mathrm{a}, \mathrm{A}$ \\
\hline \multirow{3}{*}{\multicolumn{2}{|c|}{ ANOVA ( $P$ value $)$}} & Treatment $(\mathrm{T})$ & $<0.001$ & $<0.001$ & $<0.001$ & $<0.001$ \\
\hline & & Cultivar (C) & $<0.001$ & $<0.001$ & $<0.001$ & $<0.001$ \\
\hline & & $\mathrm{T} \times \mathrm{C}$ & 0.005 & 0.046 & 0.469 & $<0.001$ \\
\hline
\end{tabular}

${ }^{\mathrm{z}} 1 \mathrm{mg}=3.5274 \times 10^{-5} \mathrm{oz}, 1 \mathrm{~cm}^{2}=0.1550$ inch $^{2}, 1 \mathrm{~mm}=0.0394$ inch.

${ }^{y}$ Mean values followed by different lowercase and capital letters differ significantly within all treatment groups and between light treatments within each cultivar, respectively (Tukey-Kramer test, $P<0.05$ )

ANOVA $=$ analysis of variance.

Table 3. Relative growth rate (RGR), net assimilation rate (NAR), and leaf area ratio (LAR) in seedlings of two strawberry cultivars grown under light-emitting diode (LED) illumination with different photoperiods (in the growth chambers) or under sunlight (in the greenhouse). Values were determined from growth parameters 0 and $38 \mathrm{~d}$ after the start of the photoperiod treatment. The light and thermal conditions in the growth chambers and the greenhouse are shown in Table 1 and Fig. 2. Data are the average of 10 replication plants $(n=10)$.

\begin{tabular}{|c|c|c|c|c|c|}
\hline Cultivar & Light source & Photoperiod (h) & $\operatorname{RGR}\left(g \cdot g^{-1} \cdot d^{-1}\right)^{z}$ & $\operatorname{NAR}\left(\mathrm{g} \cdot \mathrm{m}^{-2} \cdot \mathrm{d}^{-1}\right)^{\mathrm{z}}$ & $\operatorname{LAR}\left(\mathrm{m}^{2} \cdot \mathrm{g}^{-1}\right)^{\mathrm{z}}$ \\
\hline \multirow[t]{4}{*}{ Elan } & LEDs & 8 & $0.090 \mathrm{e}, \mathrm{C}^{\mathrm{y}}$ & $4.3 \mathrm{e}, \mathrm{C}$ & $0.022 \mathrm{ab}, \mathrm{A}$ \\
\hline & & 12 & $0.093 \mathrm{de}, \mathrm{C}$ & $5.4 \mathrm{ce}, \mathrm{C}$ & $0.018 \mathrm{ac}, \mathrm{AB}$ \\
\hline & & 24 & $0.113 \mathrm{a}, \mathrm{A}$ & $9.8 \mathrm{a}, \mathrm{A}$ & $0.012 \mathrm{e}, \mathrm{C}$ \\
\hline & Sunlight & 13.6 & $0.091 \mathrm{e}, \mathrm{C}$ & $5.0 \mathrm{de}, \mathrm{C}$ & $0.018 \mathrm{ac}, \mathrm{B}$ \\
\hline \multirow[t]{3}{*}{ Yotsuboshi } & LEDs & 8 & $0.093 \mathrm{de}, \mathrm{C}$ & $4.3 \mathrm{e}, \mathrm{B}$ & $0.022 \mathrm{a}, \mathrm{A}$ \\
\hline & & 24 & $0.109 \mathrm{ab}, \mathrm{A}$ & $6.6 \mathrm{bc}, \mathrm{A}$ & $0.017 \mathrm{~cd}, \mathrm{C}$ \\
\hline & Sunlight & 13.6 & $0.097 \mathrm{de}, \mathrm{BC}$ & $4.8 \mathrm{de}, \mathrm{B}$ & $0.020 \mathrm{ab}, \mathrm{AB}$ \\
\hline \multirow[t]{3}{*}{ ANOVA } & & Treatment $(\mathrm{T})$ & 0.009 & $<0.001$ & $<0.001$ \\
\hline & & Cultivar $(\mathrm{C})$ & $<0.001$ & $<0.001$ & $<0.001$ \\
\hline & & $\mathrm{T} \times \mathrm{C}$ & 0.015 & $<0.001$ & 0.052 \\
\hline
\end{tabular}

${ }^{\mathrm{z}} \mathrm{lg}=0.0353 \mathrm{oz}, \mathrm{l} \mathrm{g} \cdot \mathrm{m}^{-2}=0.0033 \mathrm{oz} / \mathrm{ft}^{2}, \mathrm{l} \mathrm{m}^{2} \cdot \mathrm{g}^{-1}=305.1517 \mathrm{ft}^{2} / \mathrm{oz}$.

${ }^{y}$ Mean values followed by different lowercase and capital letters differ significantly within all treatment groups and between light treatments within each cultivar, respectively (Tukey-Kramer test, $P<0.05$ )

ANOVA $=$ analysis of variance.

NAR; the NAR for seedlings grown under LEDs with the 12-, 16-, and 24 -h photoperiods were $126 \%, 179 \%$, and $228 \%$, respectively of the NAR under an 8-h photoperiod in 'Elan' vs. $114 \%, 144 \%$, and $153 \%$, respectively, in 'Yotsuboshi' (Table 3). The greater NAR with a longer photoperiod may have resulted from greater photosynthetic light-use efficiency at lower $P P F$ because $P P F$ decreased with increasing photoperiod while still providing the same DLI (Vlahos et al., 1991). In addition, the longer petioles produced under the longer photoperiods (described under "Morphological properties") may increase NAR by reducing the distance between the leaf surfaces and the light sources. On the other hand, the LAR decreased significantly with increasing photoperiod (Table 3 ) but its effect on RGR was smaller than that of NAR. The lower LAR with a longer photoperiod indicates that the longer photoperiod (or the shorter dark period) reduces leaf extension at a constant DLI.

When comparing seedling growth between the LED and sunlight treatments, the RGR of the seedlings grown under LEDs with
16- and 24-h photoperiods were significantly greater than those grown under sunlight (115\% and $124 \%$, respectively, of that under sunlight in 'Elan', vs. $111 \%$ and $112 \%$, respectively, in 'Yotsuboshi'), and the differences were significant even though DLI was equivalent in all treatments (Table 3). This indicates that seedling growth could be improved by growing under LED illumination with the same DLI as sunlight. The NAR values of seedlings grown under LED illumination with 16- and 24-h photoperiods were also significantly greater than that of seedlings grown 
under sunlight (154\% and 196\%, respectively, of that under sunlight in 'Elan' vs. $129 \%$ and $138 \%$, respectively, in 'Yotsuboshi') (Table 3), probably because the photosynthetic light-use efficiency with blue and red light is greater than other spectral regions (McCree, 1971). In addition, the greater $P P F$ of sunlight around midday (up to $1800 \mu \mathrm{mol} \cdot \mathrm{m}^{-2} \cdot \mathrm{s}^{-1}$, vs. up to $350 \mu \mathrm{mol} \cdot \mathrm{m}^{-2} \cdot \mathrm{s}^{-1}$ with the LEDs) probably lowered the photosynthetic light-use efficiency. Moreover, the diurnal temperature variation may have limited seedling growth in the greenhouse because the daily maximum temperatures $\left[>30{ }^{\circ} \mathrm{C}\right.$ (Fig. 2$\left.)\right]$ were in the range that causes heat stress in strawberry (Gulen and Eris, 2003). These results agree with the previous report that plants grown under controlled environment often show higher growth rate than under fluctuating environment (Poorter et al., 2016).

The effect of photoperiod on NAR and subsequent RGR was greater in 'Elan' than in 'Yotsuboshi' (Table 3), probably because 'Yotsuboshi' produces more leaves than 'Elan', leading to higher self- and mutual shading, which would moderate the treatment effects on NAR. Thus, the effects of photoperiod on the growth of 'Yotsuboshi' may have been underestimated.

Morphological pRoperties. The petiole $\mathrm{L}$ of seedlings of both cultivars grown under LEDs was significantly less than that of seedlings grown under sunlight, except for the 24-h photoperiod (Table 2; Fig. 4). The shorter extension growth produced under LED illumination represent a typical morphological response to light with little far-red irradiance (Shibuya et al., 2013). Among the LED treatments, the petiole was the longest with a 24 -h photoperiod, and the differences were significant for both cultivars; the petiole lengths of 'Elan' and 'Yotsuboshi' under a 24-h photoperiod were $168 \%$ and $211 \%$, respectively, of the $\mathrm{L}$ under a $16-\mathrm{h}$ photoperiod (Table 2). These results agree with previous research in which the petiole elongation of 'Elan' was stimulated by a 24 -h photoperiod compared with a $10-\mathrm{h}$ photoperiod (Sønsteby and Heide, 2007a, 2007b). The increased petiole $\mathrm{L}$ under a 24 -h photoperiod indicates that the petiole elongation is mainly affected by light intensity but not by photoperiod when DLI is equivalent, although a lower light intensity and a longer photoperiod (a shorter dark period) may have the opposite effect on stimulation of elongation. The excess elongation growth may reduce the resistance to mechanical stresses (Latimer and Mitchell, 1988). Thus, growers must balance the drawback of excess petiole elongation against the desirable increase in dry matter production when optimizing the photoperiod for growth of strawberry seedlings.
INITIATION OF FLOWER BUDS. Flower buds initiated earlier after transplanting in the 'Elan' seedlings grown under a longer photoperiod (Table 4); this agrees with a previous research that investigated longday flowering response in 'Elan' (Sønsteby and Heide, 2007a, 2007b). The number of days until flower bud initiation was about halved by growing the seedlings under LED illumination relative to sunlight. The flower bud initiation of seedlings grown under sunlight tended to be at least 9 $\mathrm{d}$ later than that of seedlings grown under LED illumination (Table 4).

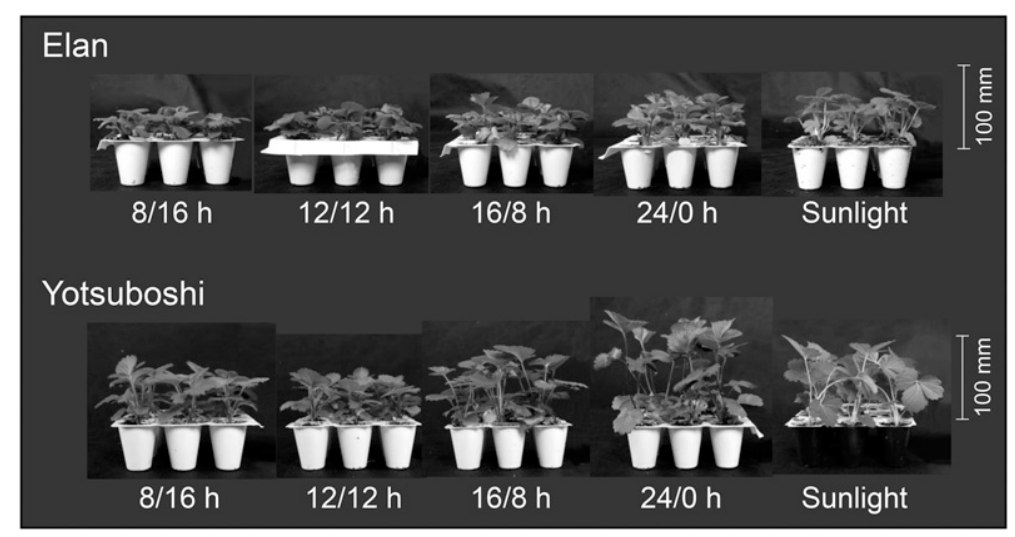

Fig. 4. Seedlings of the strawberry cultivars Elan and Yotsuboshi after growth for $38 \mathrm{~d}$ under light-emitting diode illumination (in the growth chambers) under different photoperiods (values are light/dark) and with sunlight (in the greenhouse, with a mean photoperiod of $13.6 \mathrm{~h}$ ); $1 \mathrm{~mm}=0.0394$ inch.

Table 4. Time until flower bud initiation for seedlings of two strawberry cultivars after transplantation. The strawberry seedlings were grown under lightemitting diode (LED) illumination with different photoperiods (in the growth chambers) or under sunlight (in the greenhouse) for $38 \mathrm{~d}$ and then the LED seedlings were transplanted into the greenhouse. The light and thermal conditions in the growth chambers and the greenhouse are shown in Table 1 and Figs. 2 and $3 .^{2}$

\begin{tabular}{llcc}
\hline Cultivar & Light source & Photoperiod (h) & $\begin{array}{c}\text { Time until flower } \\
\text { bud initiation (d) }\end{array}$ \\
\hline Elan & LEDs & 8 & $41 \mathrm{bc}, \mathrm{A}^{\mathrm{y}}$ \\
& 12 & $40 \mathrm{~b}, \mathrm{~A}$ \\
& 16 & $26 \mathrm{a}, \mathrm{B}$ \\
& & 24 & $26 \mathrm{a}, \mathrm{B}$ \\
Yotsuboshi & Sunlight & 13.6 & $49 \mathrm{c}, \mathrm{A}$ \\
& LEDs & 8 & $105 \mathrm{~d}, \mathrm{AB}$ \\
& & 12 & $107 \mathrm{~d}, \mathrm{~A}$ \\
& & 16 & $108 \mathrm{~d}, \mathrm{~A}$ \\
ANOVA & & 24 & $107 \mathrm{~d}, \mathrm{~A}$ \\
& Sunlight & 13.6 & $102 \mathrm{~d}, \mathrm{~B}$ \\
& & Treatment $(\mathrm{T})$ & $<0.001$ \\
& & Cultivar $(\mathrm{C})$ & $<0.001$ \\
& & T $\times \mathrm{C}$ & $<0.001$ \\
\hline
\end{tabular}

${ }^{\mathrm{z}}$ Data are the average of 25 replication plants $(n=25)$ in 'Elan', except for the plants grown under natural sunlight $(n=38)$, and of $22,20,22,20$, and 25 replication plants of 'Yotsuboshi' with photoperiods of $8,12,16$, and $24 \mathrm{~h}$ and under natural sunlight with a mean photoperiod of $13.6 \mathrm{~h}$.

${ }^{\mathrm{y}}$ Mean values followed by different lowercase and capital letters differ significantly within all treatment groups and between light treatments within each cultivar, respectively (Tukey-Kramer test, $P<0.05$ ). 
This suggests that flower initiation could be affected by interactions between photoperiod and other factors such as temperature (Sønsteby and Heide, 2007a, 2007b) and PPF fluctuations (Fig. 2). On the other hand, photoperiod had little effect and no significant effect on flower bud initiation in 'Yotsuboshi' seedlings (Table 4). Previous research suggests that flower development in 'Yotsuboshi' can be improved by a long-day treatment (Mochizuki et al., 2016; Mori et al., 2015), but the effect of a longday treatment differs between seasons (Hamano and Kimura, 2018). Sønsteby and Heide (2007b) reported that the interaction of photoperiod and temperature was cultivar-specific. Thus, to improve the flower initiation by 'Yotsuboshi' under LED illumination, it will be necessary to quantify the effects of interactions between photoperiod and other factors in future research.

Within 1 week after transplantation, $12 \%$ seedling death was observed in 'Yotsuboshi' that had been grown under LED illumination (described under "Statistical analysis"), but there was no seedling death in 'Elan' or in 'Yotsuboshi' under sunlight. This may have resulted from heat or drought stress during transplantation, although the true reasons are not clear. Such stresses during transplantation may have caused the lack of a difference in flower bud initiation rates in indoor-grown 'Yotsuboshi' seedlings (Table 4). This indicates the importance of the acclimatization process when transplanting indoor-grown strawberry seedlings to greenhouse conditions.

\section{Conclusions}

The seedling growth of the strawberry cultivars Elan and Yotsuboshi could be improved by growing under LED illumination compared with under greenhouse conditions, even though both groups of seedlings experienced about the same DLI and average temperature. In addition, flower bud initiation after transplanting could be accelerated by increasing the photoperiod in 'Elan' but not in 'Yotsuboshi'. Thus, the production of strawberry plugs under artificial lighting with an optimized photoperiod could provide high-quality transplants, although the effectiveness of this approach appears to be cultivar-specific.

\section{Literature cited}

Bentvelsen, G. and B. Bouw. 2006. Breeding ornamental strawberries. Acta Hort. 708:455-458.

Bentvelsen, G.C.M. and D. Souillat. 2017. Delizzimo®: Development of a sustainable strawberry production system in winter season. Acta Hort. 1156:603-610.

Bish, E.B., D.J. Cantliffe, and C.K. Chandler. 2001. A system for producing large quantities of greenhouse-grown strawberry plantlets for plug production. HortTechnology 11:636-638.

Bish, E.B., D.J. Cantliffe, and C.K. Chandler. 2002. Temperature conditioning and container size affect early season fruit yield of strawberry plug plants in a winter, annual hill production system. HortScience 37:762-764.

Durner, E.F. 2016. Photoperiod and temperature conditioning of 'Sweet Charlie' strawberry (Fragaria $\times$ ananassa Duch.) plugs enhances off-season production. Scientia Hort. 201:184-189.

Durner, E.F., E.B. Poling, and J.L. Maas. 2002. Recent advances in strawberry plug transplant technology. HortTechnology 12:545-550.

Gulen, H. and A. Eris. 2003. Some physiological changes in strawberry (Fragaria $\times$ ananassa 'Camarosa') plants under heat stress. J. Hort. Sci. Biotechnol. 78:894-898.

Hamano, M. and F. Kimura. 2018. Effect of nursery conditions and long-day treatment on flowering and yield of the $\mathrm{F}_{1}$-hybrid strawberry of seed propagation type 'Yotsuboshi' in summer-to-autumn production. Hort. Res. (Jpn.) 17:41-47. [Japanese text with English abstr.].

Hunt, R., D.R. Causton, B. Shipley, and A.P. Askew. 2002. A modern tool for classical plant growth analysis. Ann. Bot. 90:485-488.

Kozai, T. 2007. Propagation, grafting and transplant production in closed systems with artificial lighting for commercialization in Japan. Prop. Ornam. Plants 7:145-149.

Kozai, T., K. Ohyama, and C. Chun. 2006. Commercialized closed systems with artificial lighting for plant production. Acta Hort. 711:61-70.

Latimer, J.G. and C.A. Mitchell. 1988. Effects of mechanical stress or abscisic acid on growth, water status and leaf abscisic acid content of eggplant seedlings. Scientia Hort. 36:37-46.

López-Galarza, S., S. Bautista, A. Martínez, B. Pascual, and J.V. Maroto. 2010. Influence of substrate on strawberry plug plant production. J. Hort. Sci. Biotechnol. 85:415-420.

McCree, K.J. 1971. The action spectrum, absorptance and quantum yield of photosynthesis in crop plants. Agr. Meteorol. 9:191-216.

Mochizuki, T., T. Mori, J. Kohori, H. Kitamura, T. Inokuchi, I. Kato, K. Sone, M. Ishikawa, F. Maeda, M. Fukami, S. Isobe, and S. Sato. 2016. 'Yotsuboshi', a new $\mathrm{F}_{1}$ hybrid strawberry of seed propagation type for year-round production. Acta Hort. 1156:53-60.

Mori, T., J. Kohori, H. Kitamura, T. Inokuchi, I. Kato, K. Sone, M. Ishikawa, F. Maeda, M. Fukami, S. Isobe, and S. Sato. 2015. Development of $F_{1}$-hybrid strawberry of seed propagation type named 'Yotsuboshi' by collaborative breeding among institutes. Hort. Res. (Jpn.) 14:409-418. [Japanese text with English abstr.].

Radford, P.J. 1967. Growth analysis formulae-Their use and abuse. Crop Sci. 7:171-175.

Poorter, H., F. Fiorani, R. Pieruschka, T. Wojciechowski, W.H. Putten, M. Kleyer, U. Schurr, and J. Postma. 2016. Pampered inside, pestered outside? Differences and similarities between plants growing in controlled conditions and in the field. New Phytol. 212:838-855.

Shibuya, T., S. Takahashi, R. Endo, and Y. Kitaya. 2013. Height-convergence pattern in dense plant stands is affected by red-to-far-red ratio of background illumination. Scientia Hort. 160:65-69.

Sønsteby, A. and O.M. Heide. 2007a. Quantitative long-day flowering response in the perpetual-flowering Fl strawberry cultivar Elan. J. Hort. Sci. Biotechnol. 82:266-274.

Sønsteby, A. and O.M. Heide. 2007b. Long-day control of flowering in everbearing strawberries. J. Hort. Sci. Biotechnol. 82:875-884.

Vlahos, J.C., E. Heuvelink, and G.F.P. Martakis. 1991. A growth analysis study of three Achimenes cultivars grown under three light regimes. Scientia Hort. $46: 275-282$. 